\title{
Atrial Natriuretic Polypeptide Inhibits Hypertrophy of Vascular Smooth Muscle Cells
}

Hiroshi Itoh, Richard E. Pratt, and Victor J. Dzau

Molecular and Cellular Vascular Research Laboratory, Division of Vascular Medicine and Atherosclerosis, Department of Medicine, Brigham and Women's Hospital and Harvard Medical School, Boston, Massachusetts 02115

\begin{abstract}
Vascular remodeling is central to the pathophysiology of hypertension and atherosclerosis. Recent evidence suggests that vasoconstrictive substances, such as angiotensin II (AII), may function as a vascular smooth muscle growth promoting substance. To explore the role of the counterregulatory hormone, atrial natriuretic polypeptide (ANP) in this process, we examined the effect of ANP (alpha-rat ANP [1-28]) on the growth characteristics of cultured rat aortic smooth muscle (RASM) cells. ANP $\left(10^{-7} \mathrm{M}\right)$ significantly suppressed the proliferative effect of $1 \%$ and $5 \%$ serum as measured by ${ }^{3} \mathrm{H}$-thymidine incorporation and cell number, confirming $\mathrm{ANP}$ as an antimitogenic factor. In quiescent RASM cells, ANP $\left(1^{-7}, 10^{-6} \mathrm{M}\right)$ significantly suppressed the basal incorporations of ${ }^{3} \mathrm{H}$-uridine and leucine by 50 and $30 \%$, respectively. ANP $\left(10^{-7}, 10^{-6} \mathrm{M}\right)$ also suppressed AII-induced RNA and protein syntheses (by $30-40 \%$ ) with the concomitant reduction of the cell size. Furthermore, ANP also significantly attenuated the increase of ${ }^{3} \mathrm{H}$-uridine and leucine incorporations caused by transforming growth factor- $\beta\left(4 \times 10^{-11}, 4 \times 10^{-10} \mathrm{M}\right)$, a potent hypertrophic factor. These results indicate that ANP possesses an antihypertrophic action on vascular smooth muscle cells. Downregulation of protein kinase $C$ by 24-h treatment with phorbol 12,13-dibutyrate did not inhibit ANP-induced suppression on ${ }^{3} \mathrm{H}$-uridine incorporation. Based on the observation that ANP was more potent than a ring-deleted analogue of ANP on inhibiting ${ }^{3} \mathbf{H}$-uridine incorporation, we conclude that the ANP's inhibitory effect is primarily mediated via the activation of a guanylate cyclase-linked ANP receptor(s). Indeed 8-bromo cGMP mimicked the antihypertrophic action of ANP. Accordingly, we speculate that in addition to its vasorelaxant and natriuretic effects, the antihypertrophic action of ANP observed in the present study may serve as an additional compensatory mechanism of ANP in hypertension. (J. Clin. Invest. 1990. 86:1690-1697.) Key words: angiotensin II • transforming growth factor- $\beta$ • cyclic GMP • growth factor $\bullet$ hypertension
\end{abstract}

\section{Introduction}

Blood pressure homeostasis is achieved by a balance of vasoconstrictive and vasodilatory forces. The potent vasorelaxant

Address correspondence to Victor J. Dzau, M.D., Cardiovascular Division, Falk Cardiovascular Research Center, Stanford University Medical Center, 300 Pasteur Drive, Stanford, CA 94305. 1990

Received for publication 2 May 1990 and in revised form 18 July

J. Clin. Invest.

(c) The American Society for Clinical Investigation, Inc. 0021-9738/90/11/1690/08 $\$ 2.00$

Volume 86, November 1990, 1690-1697 and diuretic-natriuretic hormone, atrial natriuretic polypeptide $(A N P)^{1}(1-4)$, is an important counterregulatory substance to vasoconstrictive hormones, such as angiotensin II (AII). In hypertension, the synthesis and secretion of ANP may be increased to compensate for the enhanced vasoconstriction. Indeed, plasma ANP levels are reported to be elevated both in patients with hypertension (5) and in several hypertensive animals, such as the spontaneously hypertensive rats (SHR) $(6,7)$ and deoxycorticosteroid acetate (DOCA)-salt rats (8). Recently it has been demonstrated that chronic blockade of endogenous circulating ANP by the monoclonal antibody against ANP accelerates the development of hypertension in SHR and DOCA-salt rats. This result supports the compensatory role of ANP in hypertension and extends further the concept that augmented secretion of ANP could represent an antihypertensive deterrent mechanism (9).

Excessive vascular smooth muscle cell growth has been highlighted recently in the pathophysiology of hypertension and atherosclerosis. Indeed, one of the hallmarks of chronic hypertension is a generalized increase in the smooth muscle mass of the blood vessel wall (10). While acute hypertensive models (such as aortic coarctation) or experimental injury models of atherosclerosis are characterized by vascular smooth muscle cell proliferation (hyperplasia) $(11,12)$ chronic hypertension models, such as the Goldblatt two-kidney one-clip hypertensive rats and SHR exhibit aortic smooth muscle cell hypertrophy with an increase in polyploidy without an increase in cell number $(13,14)$.

Recent evidence suggests that in addition to several growth factors, such as platelet-derived growth factor (PDGF) and transforming growth factor- $\beta$ (TGF- $\beta$ ), circulating or paracrine-autocrine vasoactive peptides may influence vessel wall growth. For example, AII enhances serum-stimulated proliferation of human aortic smooth muscle cells (15), and induces hypertrophy in quiescent vascular smooth muscle cells in serum-free medium (16). AII has been also shown to stimulate the expression of the protooncogene, c-fos (17), one of the earliest genetic programs associated with growth. We demonstrated further that AII can induce sequentially c-myc and PDGF mRNA expressions in these cultured vascular smooth muscle cells (18). The in vivo data that the angiotensin-converting enzyme inhibitor captopril prevented smooth muscle cell growth to a much greater extent than propranolol or hydralazine for a similar reduction in blood pressure (19) supports the role of AII in the promotion of vascular smooth muscle cell growth

1. Abbreviations used in this paper: AII, angiotensin II; ANP, atrial natriuretic polypeptide; DOCA, deoxycorticosteroid acetate; PDGF, platelet-derived growth factor; RASM, rat aortic smooth muscle; SHR, spontaneously hypertensive rats; TGF- $\beta$, transforming growth factor$\beta$. 
Because ANP is known to be a physiological antagonist to AII in vasoconstriction, secretion of aldosterone $(3,4)$, or several centrally mediated effects (20), we hypothesize that ANP can also inhibit vascular smooth muscle cell growth, especially that induced by AII. In this study we examined the antigrowth properties of ANP on vascular smooth muscle cells. Indeed, our data suggest that ANP is an inhibitor of vascular smooth muscle cell growth to many factors (e.g. serum, angiotensin, and TGF- $\beta$ )

\section{Materials and Methods}

Cell culture. RASM cells (passage 5-10) were isolated and cultured according to the method of Owens et al. (21). They were maintained in 1:1 mixture of DME and Ham's F12 medium (Gibco, Grand Island, NY) with $10 \%$ FCS, penicillin $(100 \mathrm{U} / \mathrm{ml})$, streptomycin $(100 \mu \mathrm{g} / \mathrm{ml})$, and $25 \mathrm{mM}$ Hepes, pH 7.4. Cells were incubated at $37^{\circ} \mathrm{C}$ in a humidified atmosphere of $95 \%$ air- $5 \% \mathrm{CO}_{2}$ with media changes every $2-3 \mathrm{~d}$. In preparation for experiments, the cells were made quiescent by placing them for $48 \mathrm{~h}$ in a defined serum-free (DSF) medium containing insulin $\left(5 \times 10^{-7} \mathrm{M}\right)$ (Sigma Chemical Co., St. Louis, MO), transferrin $(5 \mu \mathrm{g} / \mathrm{ml})$ (Sigma Chemical Co.), and ascorbate $(0.2 \mathrm{mM})$ (Sigma Chemical Co.). This medium has been shown to maintain smooth muscle cells in a quiescent, noncatabolic state and to promote expression of smooth muscle cell-specific contractile proteins for an extended period of time (21).

Growth curves. For the determination of cell numbers, RASM cells were plated into 24-well culture dishes (Costar Corp., Cambridge, MA) at $1 \times 10^{4}$ cells/well and grown in Medium 199 containing $10 \%$ FCS for $24 \mathrm{~h}$, then switched to the same medium containing either 1 or $5 \%$ FCS for $4 \mathrm{~d}$, with media changes every $24 \mathrm{~h}$. Cultures were washed with a calcium- and magnesium-free PBS $\left(\mathrm{NaCl}, 137 \mathrm{mM} ; \mathrm{Na}_{2} \mathrm{HPO}_{4}, 8.1\right.$ $\left.\mathrm{mM} ; \mathrm{KCl}, 2.7 \mathrm{mM} ; \mathrm{KH}_{2} \mathrm{PO}_{4}, 1.5 \mathrm{mM} ; \mathrm{pH} 7.4\right)$ and harvested with trypsin-EDTA $(0.05 \%$ trypsin, $0.02 \%$ EDTA, Gibco) solution. Counts were performed by hemocytometer measurement immediately after the cell harvest.

Determination of DNA, protein, and RNA syntheses. Relative rates of DNA, protein, and RNA syntheses were assessed by determination of tritiated thymidine, leucine, and uridine incorporations, respectively, into TCA-precipitable material. Quiescent RASM cells grown in 24-well Costar culture dishes were pulsed for $4 \mathrm{~h}$ with tritiated thymidine $(10 \mu \mathrm{Ci} / \mathrm{ml})$, leucine $(10 \mu \mathrm{Ci} / \mathrm{ml})$, or uridine $(2 \mu \mathrm{Ci} / \mathrm{ml})$, washed twice with cold PBS, twice with $10 \%$ (wt/vol) cold TCA and incubated with $10 \%$ TCA at $4^{\circ} \mathrm{C}$ for $30 \mathrm{~min}$. Cells were then rinsed in ethanol (95\%) and dissolved in $0.25 \mathrm{~N} \mathrm{NaOH}$ at $4^{\circ} \mathrm{C}$ for $2 \mathrm{~h}$, neutralized, the radioactivity determined by liquid scintillation spectrometry.

Flow microfluorimetric analysis of cell volume and cellular total protein content. Quiescent RASM cells grown in T-25 flasks (Corning Laboratory Science Co., Corning, NY) were washed with PBS and harvested with trypsin EDTA solution described above, and then pelleted by centrifugation $(113 \mathrm{~g}, 6 \mathrm{~min})$. The cells were resuspended in PBS, fixed at $4^{\circ} \mathrm{C}$ in $2 \%$ paraformaldehyde and stained with fluorescein isothiocyanate $(100 \mathrm{ng} / \mathrm{ml}$, FITC, Sigma Chemical Co.) for 30 $\mathrm{min}$ at room temperature. All samples for cell volume and protein determination were kept at $4^{\circ} \mathrm{C}$ in the dark and were analyzed within 3 $\mathrm{h}$ after staining on a FACSI cell analyzer (Becton Dickinson, Sunnyvale, CA).

Materials. Alpha-rat ANP [1-28], AII, and TGF- $\beta$ from human platelets were obtained from Peninsula Laboratories Inc. (Belmont, CA), Sigma Chemical Co., and Calbiochem-Behring Corp. (La Jolla, CA), respectively. 8-Bromo cyclic GMP (cGMP), phorbol 12-myristate 13-acetate (PMA), and phorbol 12,13-dibutyrate (PDBu) were purchased from Sigma Chemical Co. Des $\left[\mathrm{Gln}^{18}, \operatorname{Ser}^{19}, \mathrm{Gly}^{20}, \mathrm{Leu}^{21}, \mathrm{Gly}^{22}\right]-$ ANP[4-23]- $\mathrm{NH}_{2}$ (C-ANP [4-23]) was donated from Dr. Kazuwa Nakao in Kyoto University School of Medicine. These compounds were dissolved in PBS and added independently or together to the media of cultured RASM.
Statistical analysis. All values are expressed as mean \pm SEM, $n$ $=6-12$ in three to six separate experiments. Analysis of variance with subsequent Duncan's test was used to determine significant differences in multiple comparisons. $P<0.05$ was considered significant.

\section{Results}

Inhibition of serum-stimulated cell proliferation by ANP. Table I shows the effect of daily administration of ANP (alpha-rat ANP [1-28]; $10^{-7} \mathrm{M}$ ) on the growth of RASM cells stimulated by FCS. After 4 d, ANP-treated cell cultures maintained in both 1 and 5\% FCS showed significantly lower cell number than the respective vehicle-treated cell cultures. In 1\% FCS, ANP reduced the cell number by $35 \%$ as compared to cells treated with vehicle. In $5 \%$ FCS, a $27 \%$ reduction in cell number was observed with ANP treatment.

ANP exhibited significant inhibitory effect on ${ }^{3} \mathrm{H}$-thymidine incorporation of RASM cells as shown in Table I. In these experiments, RASM cells, upon confluency, were cultured in DSF media for $2 \mathrm{~d}$ to induce quiescence. The cell cultures were then divided into two experimental groups; one group continued to be maintained in DSF media (basal group), and the other group was cultured in DMEM/Ham's F12 containing $1 \%$ FCS (1\% FCS group). Both groups then received either vehicle (PBS) or ANP $10^{-7} \mathrm{M} .16 \mathrm{~h}$ after the addition of ANP, RASM cells were pulse-labeled with ${ }^{3} \mathrm{H}$-thymidine $(10 \mu \mathrm{Ci} / \mathrm{ml})$ for $4 \mathrm{~h}$. Our results demonstrated that in the absence of ANP, the $1 \%$ FCS-treated group exhibited nearly a fivefold increase of ${ }^{3} \mathrm{H}$-thymidine incorporation as compared to DSF group (basal vs $1 \%$ FCS in vehicle-treated groups). ANP $\left(10^{-7} \mathrm{M}\right)$ reduced ${ }^{3} \mathrm{H}$-thymidine incorporation to a comparable extent (50-60\% reduction), in both the basal and $1 \%$ FCS-stimulated cultures.

Hypertrophic action of AII on postconfluent RASM cells. AII exhibited concentration-dependent stimulatory effects on ${ }^{3} \mathrm{H}$-uridine and leucine incorporations in quiescent RASM cells with the maximal increase of $130 \%$ for ${ }^{3} \mathrm{H}$-uridine and $70 \%$ for ${ }^{3} \mathrm{H}$-leucine incorporations occurring at $100 \mathrm{nM}$. The half-maximal AII concentration for these effects was $\sim 10 \mathrm{nM}$ (Fig. 1 B). No further increase was observed at the higher concentration of AII.

The time course of AII-induced ${ }^{3} \mathrm{H}$-uridine and leucine incorporations is shown in Fig. $1 A$. The stimulatory effect of AII on RNA synthesis was first observed after incubation for 4-8 $\mathrm{h}$, and on protein synthesis, 8-12 h. The peak effects were observed 12-16 $\mathrm{h}$ after AII exposure.

Table I. Effect of ANP on ${ }^{3} \mathrm{H}$-Thymidine Incorporation and Serum-stimulated Proliferation of RASM Cells

\begin{tabular}{|c|c|c|c|c|}
\hline \multirow[b]{2}{*}{ Group } & \multicolumn{2}{|c|}{${ }^{3} \mathrm{H}$-Thymidine incorporation } & \multicolumn{2}{|c|}{ Cell number } \\
\hline & Basal & $1 \%$ FCS & $1 \%$ FCS & $5 \%$ FCS \\
\hline & \multicolumn{2}{|c|}{ cpm/well } & \multicolumn{2}{|c|}{$\times 10^{3} /$ well } \\
\hline $\begin{array}{l}\text { Vehicle } \\
\text { ANP } 10^{-7} \mathrm{M}\end{array}$ & $\begin{array}{r}22,100 \pm 690 \\
9690 \pm 460^{\ddagger}\end{array}$ & $\begin{array}{l}99,000 \pm 5780^{*} \\
38,100 \pm 2970^{* \ddagger}\end{array}$ & $\begin{array}{l}33.1 \pm 1.9 \\
21.4 \pm 1.9^{\ddagger}\end{array}$ & $\begin{array}{l}46.8 \pm 3.2^{8} \\
34.0 \pm 2.6^{6}\end{array}$ \\
\hline
\end{tabular}

Values are means $\pm \mathrm{SEM}, n=6$ in ${ }^{3} \mathrm{H}$-thymidine incorporation and

$n=12$ in cell number.

$* P<0.05$, significantly different from basal group.

$¥ P<0.05$, significantly different from vehicle group.

${ }^{8} P<0.05$, significantly different from $1 \%$ FCS group. 

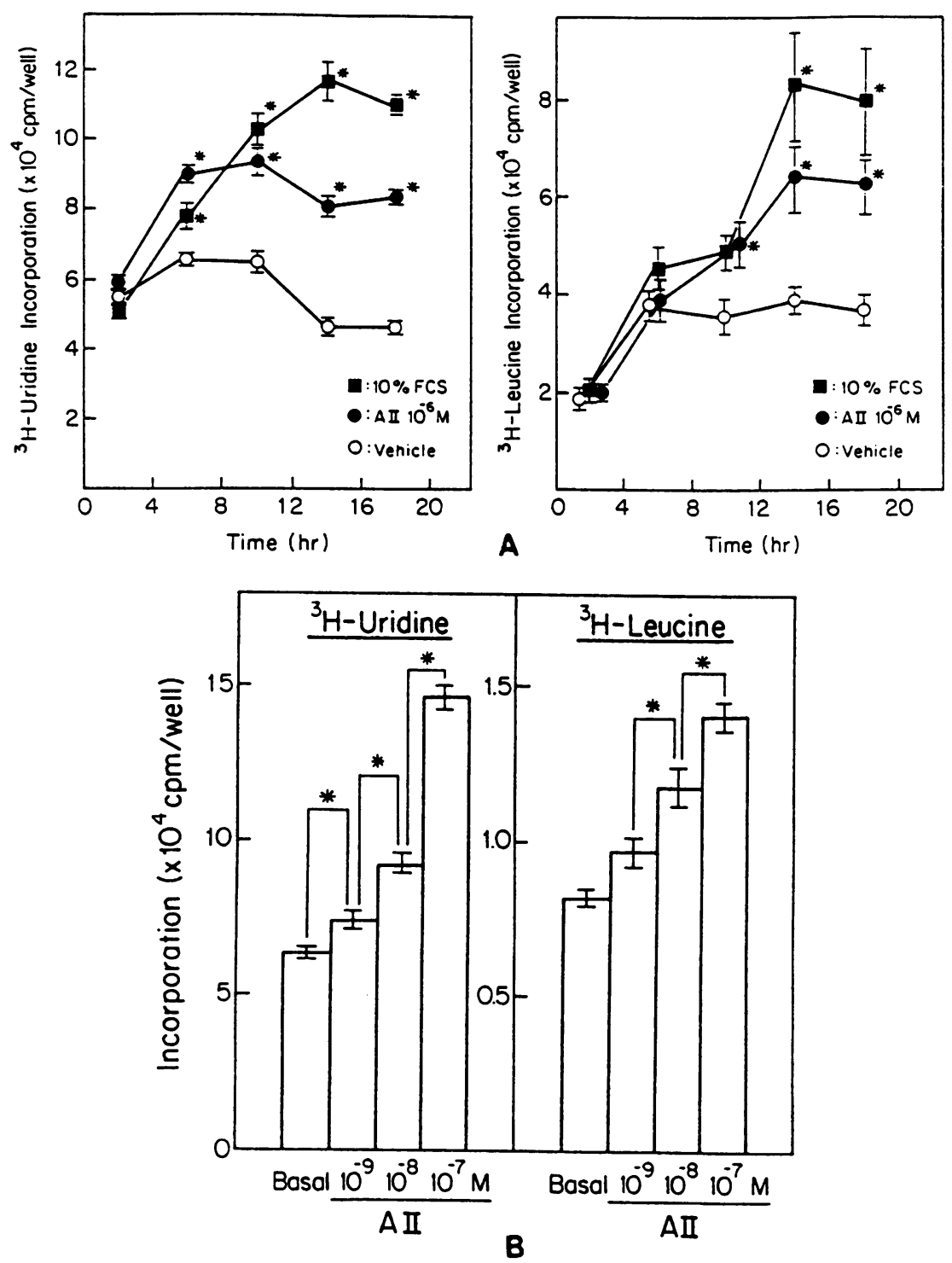

Figure 1. Stimulatory effect of AII on the incorporations of ${ }^{3} \mathrm{H}$-uridine and leucine in RASM cells. $(A)$ Time course for induction of RNA (left) and protein (right) syntheses by AlI. Quiescent RASM cells ( $n=8$ in each group) were incubated for $0,4,8,12$, and $16 \mathrm{~h}$ with vehicle (PBS) or 1 $\mu \mathrm{M}$ AII or $10 \% \mathrm{FCS}$, and pulse-labeled with 2 $\mu \mathrm{Ci} / \mathrm{ml}$ of ${ }^{3} \mathrm{H}$-uridine or $10 \mu \mathrm{Ci} / \mathrm{ml}$ of ${ }^{3} \mathrm{H}$-leucine for additional $4 \mathrm{~h} .{ }^{3} \mathrm{H}$-Uridine and leucine incorporations into TCA-precipitable material were performed as described above. ${ }^{*} P<0.05$ is significantly different from time-dependent vehicletreated control group. (B) Concentration dependence of AII-induced RNA (left) and protein (right) syntheses in RASM cells. Cultures of quiescent RASM cells ( $n=8-12$ in each group) were incubated for $16 \mathrm{~h}$ with AII (1-100 nM) and then pulse-labeled with ${ }^{3} \mathrm{H}$-uridine or leucine for $4 \mathrm{~h}$. RNA and protein syntheses were measured by incorporation into TCA-precipitable material, ${ }^{*} P$ $<0.05$.

To verify the hypertrophic action of AII on RASM cells, cell size and cellular protein content were assessed by flow cytometric analysis. Daily administration of AII at the concentration of $10^{-8}, 10^{-7}$, and $10^{-6} \mathrm{M}$ for $3 \mathrm{~d}$ caused increases of cell size $(6.3 \pm 0.7 \%, n=5 ; 23.3 \pm 1.9 \%, n=8 ; 49.1 \pm 5.1 \%, n=4$ over control, respectively) and of cellular protein content (9.7 $\pm 7.3 \%, n=7 ; 22.4 \pm 7.7 \%, n=6 ; 24.8 \pm 4.9 \%, n=4$ over control, respectively).

We also studied the mitogenic influence of AII on RASM cells. As described by previous investigations, we did not observe any significant effects of AII on the cell number, ${ }^{3} \mathrm{H}$-thymidine incorporation, or ${ }^{3} \mathrm{H}$-thymidine labeling index determined by ${ }^{3} \mathrm{H}$-thymidine autoradiography (data not shown).

Antihypertrophic action of ANP on postconfluent RASM cells. Fig. 2 shows the effect of ANP on ${ }^{3} \mathrm{H}$-uridine and leucine incorporations of postconfluent RASM cells in the basal state in DSF media or stimulated by AII $\left(10^{-8} \mathrm{M}\right)$. ANP inhibited RNA and protein syntheses of RASM cells. The maximal inhibition was seen at an ANP concentration of $100 \mathrm{nM}$, and an $\mathrm{ED}_{50}$ at $10-100 \mathrm{nM}$ for both the basal state and AII-stimulated state. The inhibitory action of ANP on ${ }^{3} \mathrm{H}$-uridine incorpora- tion was, however, more prominent in the basal state than in AII-stimulated state (50 vs. $30 \%$ reduction at the concentration of $10^{-7} \mathrm{M}$ of ANP).

In another series of experiments we demonstrated that ANP did not cause the loss of cells at the confluent state. $20 \mathrm{~h}$ after the addition of ANP, $<1 \%$ of cells were found to be present in the supernatant media.

Because DSF medium contains insulin $\left(5 \times 10^{-7} \mathrm{M}\right)$, we examined whether the inhibitory action of ANP on RNA and protein syntheses in the basal state is mediated via a blocking action of ANP on insulin effect. ${ }^{3} \mathrm{H}$-Uridine incorporation of postconfluent RASM cells cultured with DMEM/Ham's F12 without insulin for $2 \mathrm{~d}$, was $24,000 \pm 1,900 \mathrm{cpm} /$ well $(n=8 ; 4 \mathrm{~h}$ pulse-labeling with $2 \mu \mathrm{Ci} / \mathrm{ml}$ of ${ }^{3} \mathrm{H}$-uridine); that of RASM cells cultured with DMEM/Ham's F12 containing insulin was $31,000 \pm 2,200 \mathrm{cpm} /$ well $(n=8)$. ANP $\left(10^{-7} \mathrm{M}\right)$ reduced ${ }^{3} \mathrm{H}-$ uridine incorporation significantly almost to the same extent in these two groups $(18,300 \pm 1,500 \mathrm{cpm} /$ well in the cells grown in the medium without insulin, $n=8$, and $23,200 \pm 2,300$ $\mathrm{cpm} /$ well in the cells with the medium containing insulin, $n$ $=8$ ). 


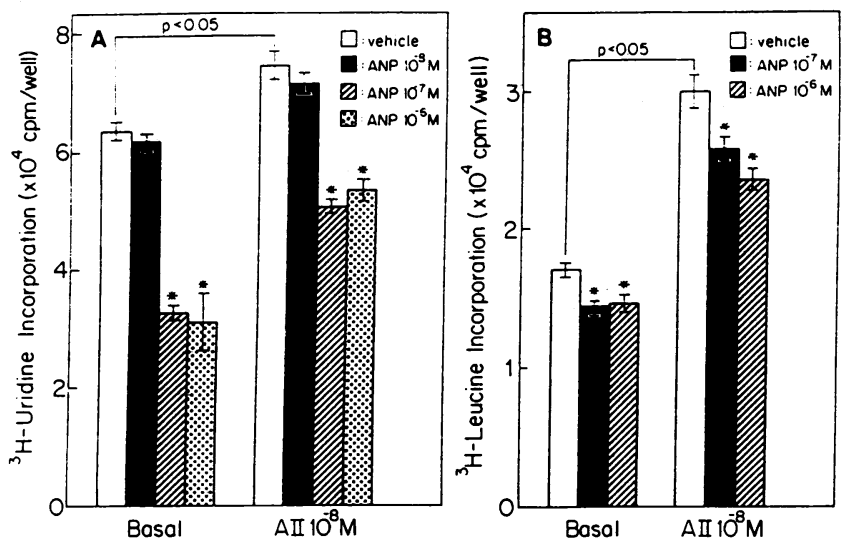

Figure 2. Inhibitory effect of ANP on ${ }^{3} \mathrm{H}$-uridine $(A)$ and leucine $(B)$ incorporations in quiescent or AII-stimulated RASM cells. ANP (alpha-rat ANP [1-28]) $\left(10^{-8}-10^{-6} \mathrm{M}\right)$ was added to quiescent RASM cells in the presence or absence of AII $\left(10^{-8} \mathrm{M}\right)$ for $16 \mathrm{~h}$ and then pulsed for $4 \mathrm{~h}$ with ${ }^{3} \mathrm{H}$-uridine $(2 \mu \mathrm{Ci} / \mathrm{ml})$ or leucine $(10 \mu \mathrm{Ci} / \mathrm{ml})$. Values are mean $\pm \mathrm{SEM}$ of $n=8-12 .{ }^{*} P<0.05$ is significantly different from control groups treated with vehicle or AII alone.

Fig. 3 shows histograms of cell size and cellular protein content of postconfluent RASM cells defined by flow microfluorimetric analysis. Daily treatment with $\operatorname{ANP}\left(10^{-7} \mathrm{M}, 4 \mathrm{~d}\right.$, $n=4)$ tended to reduce the cell size and cellular protein content $(-11.4 \pm 3.2 \%, 0.05<P<0.1$ and $-11.5 \pm 3.9 \%, 0.05<P$ $<0.1$, respectively, over control) and caused a significant leftward shift in cell size-and protein content histograms in AII $\left(10^{-7} \mathrm{M}, 4\right.$ days)-treated cell groups (AII alone vs. AII + ANP; $65.4 \pm 8 \%$ vs. $12.8 \pm 3 \%, P<0.01$ in cell size; $24.8 \pm 2.8 \%$ vs. $0.3 \pm 4.6 \%, P<0.01$ in protein content over control). This result documented further the inhibitory effect of ANP on cellular hypertrophy of RASM cells.
To examine further the antihypertrophic effect of ANP on RASM cells, we studied ANP effect on RNA and protein syntheses stimulated by TGF- $\beta$, which has been demonstrated to cause hypertrophy in RASM cells (22). Fig. 4 depicts TGF- $\beta$ induced RNA and protein syntheses in RASM cells and the effect of ANP on these parameters. TGF- $\beta$ exhibited potent stimulatory action on ${ }^{3} \mathrm{H}$-uridine and leucine incorporations with the threshold of $40 \mathrm{pM}$ for ${ }^{3} \mathrm{H}$-uridine and $400 \mathrm{pM}$ for ${ }^{3} \mathrm{H}$-leucine incorporations, respectively. As shown in Fig. 4, ANP at $100 \mathrm{nM}$ added simultaneously with TGF- $\beta$ signifcantly attenuated TGF- $\beta$-induced ${ }^{3} \mathrm{H}$-uridine and leucine incorporations.

Receptor specificity of antihypertrophic action of ANP. Three distinct ANP receptors have been identified to date. The ANP-A and B receptors are coupled to particulate guanylate cyclase and CGMP is considered to be the intracellular second messenger $(23,24)$. A third receptor, the ANP-C receptor, possesses a short intracellular $\mathrm{COOH}$-terminal domain and shows relatively high binding affinities with wide range of $\mathrm{NH}_{2}$ - or $\mathrm{COOH}$-terminally-truncated ANP-related peptides $(25,26)$. We, therefore, examined which of the ANP receptor(s) is responsible for the antihypertrophic action of ANP. It has been reported and we also confirmed in our RASM cells that a ring-deleted analogue of ANP, des $\left[\mathrm{Gln}^{18}, \operatorname{Ser}^{19}, \mathrm{Gly}^{20}\right.$,

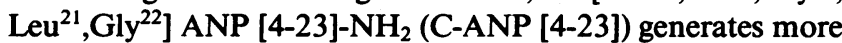
than two orders of magnitude less intracellular cGMP than ANP [1-28] and exhibits higher affinity to C-receptor $(26,27)$. As shown in Fig. 5, the inhibitory effect of C-ANP [4-23] $\left(10^{-7}\right.$ M) on ${ }^{3} \mathrm{H}$-uridine incorporation of RASM cells in the basal state was significantly weaker than that of ANP [1-28] at the same concentration. Furthermore, C-ANP [4-23] did not suppress AII $\left(10^{-8}\right.$ and $\left.10^{-7} \mathrm{M}\right)$-induced increase of ${ }^{3} \mathrm{H}$-uridine incorporation, whereas ANP [1-28] caused significant reduction. In another series of experiments, the inhibitory effect of C-ANP [4-23] at the concentration of $10^{-6} \mathrm{M}$ on the basal uridine incorporation was almost the same as that at the con-
CELL SIZE
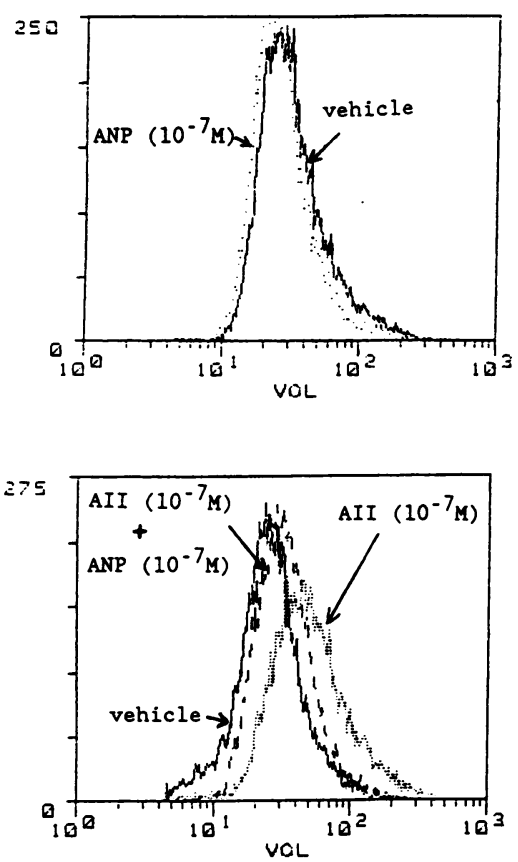

PROTEIN CONTENT
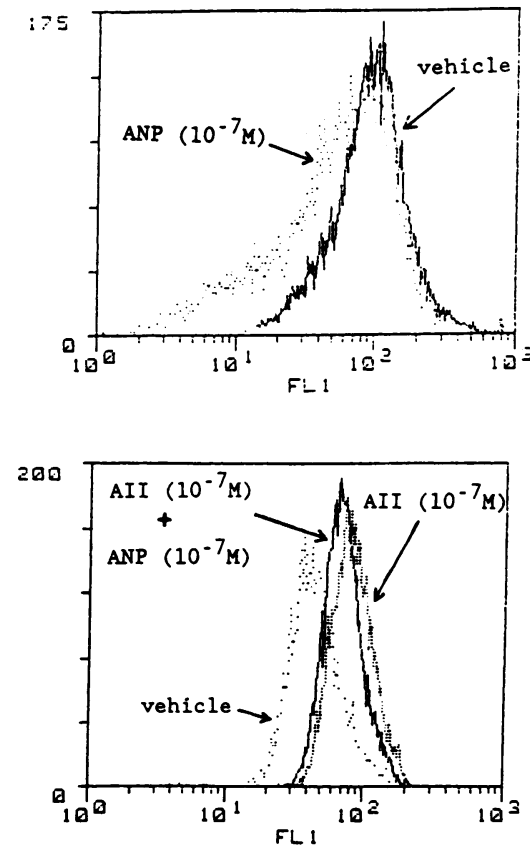

Figure 3. Histograms of relative cell size (left) and relative protein content (right) of postconfluent cells as measured by flow microfluorimetric analysis of fluorescein isothiocyanatestained paraformaldehyde fixed RASM cells. RASM cells were plated on T-25 flasks and fed DMEM/Ham's F12 until confluent. Cultures were maintained in DSF media for $2 \mathrm{~d}$ to induce quiescence and then treated with vehicle; ANP $\left(10^{-7} \mathrm{M}\right)$; AII $\left(10^{-7} \mathrm{M}\right)$; and ANP $\left(10^{-7} \mathrm{M}\right)$ plus AII $\left(10^{-7} \mathrm{M}\right)$ for $4 \mathrm{~d}$. Analyses of 5,000 or 10,000 cells were performed on a Becton Dickinson cell sorter. The data presented are typical of four such experiments. $y$ Axis shows cell numbers and $x$-axis represents relative cell size or protein content. 

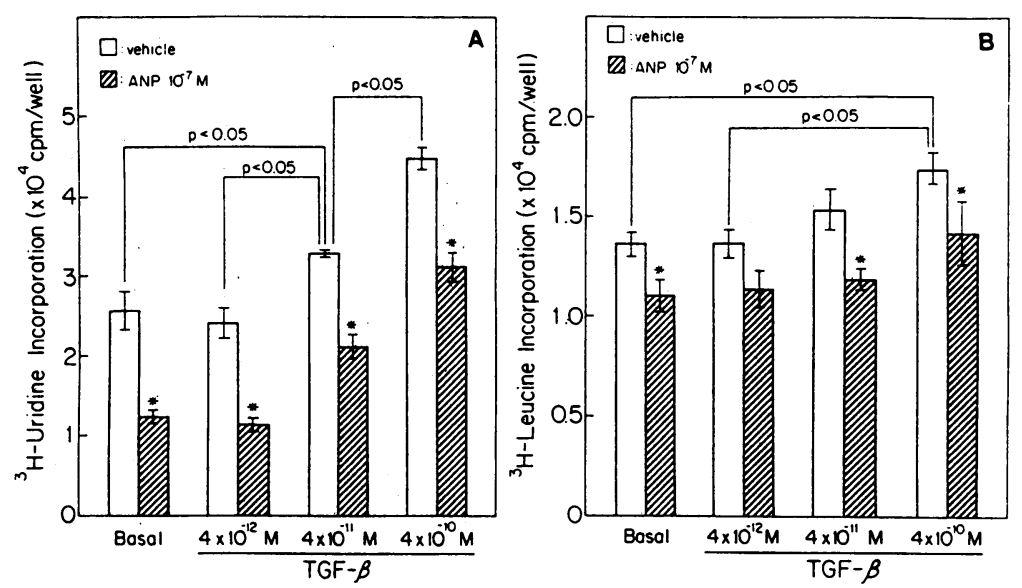

Figure 4. Inhibitory effect of ANP on TGF- $\beta$-induced RNA $(A)$ and protein $(B)$ syntheses in RASM cells. TGF- $\beta$ with various concentrations (4-400 pM) with/ without ANP (alpha-rat ANP [1-28]; $100 \mathrm{nM}$ ) was administered to quiescent RASM cells. After $16 \mathrm{~h}$, these cells were pulse-labeled with ${ }^{3} \mathrm{H}$-uridine $(A)$ or leucine $(B)$ for $4 \mathrm{~h}$. Each group consists of $n=6-8$ and values are mean \pm SEM. ${ }^{*} P<0.05$ is significantly different from respective control groups without the addition of ANP. centration of $10^{-7} \mathrm{M}(-29.7 \pm 10.4 \%, n=4$, vs. $-26.2 \pm 6.7 \%, n$ $=4$, over control). C-ANP [4-23] $\left(10^{-6} \mathrm{M}\right)$ also did not suppress AII $\left(10^{-8} \mathrm{M}\right)$-induced RNA synthesis.

Because cGMP is thought to be the second messenger for the ANP-A and B receptors, we tested the effect of 8-bromo cGMP on ${ }^{3} \mathrm{H}$-uridine incorporation in the basal and AII $\left(10^{-8}\right.$ M)-stimulated cells (Fig. 6). 8-Bromo cGMP $\left(10^{-3}-10^{-2} \mathrm{M}\right)$ suppressed significantly the basal and AII-stimulated rates of RNA synthesis.

Recently the role of protein kinase $\mathrm{C}$ in mediating protein synthesis in RASM cells has been suggested (28). Accordingly, we examined the possible involvement of protein kinase $C$ in the antihypertrophic action of ANP. As shown in Table II, the

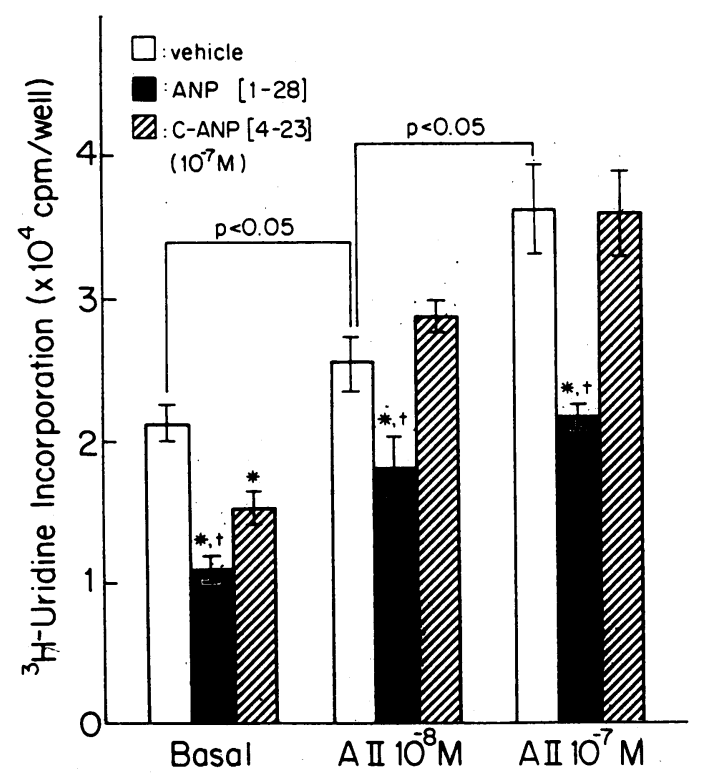

Figure 5. Specificity of inhibitory effect of ANP on RNA synthesis in RASM cells. ANP [1-28] or a ring-deleted analogue of ANP, C-ANP [4-23] at the concentration of $10^{-7} \mathrm{M}$ was added to the media of quiescent RASM cells in the basal state or stimulated with AII $\left(10^{-8}-\right.$ $10^{-7} \mathrm{M}$ ). ANPs and AII were administered simultaneously and the cells were incubated for $16 \mathrm{~h}$ and pulsed with ${ }^{3} \mathrm{H}$-uridine $(2 \mu \mathrm{Ci} / \mathrm{ml})$ for the following $4 \mathrm{~h}$. Values are mean $\pm \operatorname{SEM}(n=8) .{ }^{*} P<0.05$ is significantly different from respective control groups without the treatment of ANPs. ${ }^{+} P<0.05$ is significantly different from respective groups treated with C-ANP [4-23]. phorbol ester, phorbol 12-myristate 13-acetate (PMA), which is known to activate protein kinase $\mathrm{C}$ at the concentration of $10^{-8} \mathrm{M}$, caused significant increase of ${ }^{3} \mathrm{H}$-uridine incorporation $16 \mathrm{~h}$ after its addition ( $4 \mathrm{~h}$ pulse-labeling with $2 \mu \mathrm{Ci} / \mathrm{ml}$ of ${ }^{3} \mathrm{H}$-uridine, untreated cells in Table II). In these cells in which a protein kinase $\mathrm{C}$-dependent pathway for RNA synthesis is present, ANP $\left(10^{-7} \mathrm{M}\right)$ inhibited basal ${ }^{3} \mathrm{H}$-uridine incorporation and significantly blunted the PMA-induced increase of ${ }^{3} \mathrm{H}$-uridine incorporation. To down-regulate protein kinase $\mathrm{C}$ activity, we pretreated RASM cells with $4 \mu \mathrm{M}$ phorbol 12,13dibutyrate (PDBu) for $24 \mathrm{~h}$ (PDBu-treated cells in Table II). This condition has been shown to down-regulate protein kinase C. Under this condition, the acute PMA-induced ${ }^{3} \mathrm{H}$-uridine incorporation was almost completely abolished $(-2.2 \pm 4.4 \%$ increase over control). Interestingly, in these protein kinase C down-regulated cells, ANP still exerted the inhibitory effect on RNA synthesis.

\section{Discussion}

ANP is an important counterregulatory hormone to the vasoconstrictive sodium retentive hormones, such as AII $(3,4)$. Because our recent data suggest that these vasoconstrictive substances are also growth promoting substances of vascular smooth muscle, it is logical to question whether ANP is an inhibitor of vascular smooth muscle cell growth and if it antagonizes AII's effect on vascular hypertrophy.

Several lines of evidence in vitro demonstrate a hypertrophic effect of AII $(16,28)$ on vascular smooth muscle cells. Our

Table II. Effect of Phorbol 12,13-Dibutyrate (PDBu) Treatment on Inhibitory Action of ANP on ${ }^{3} \mathrm{H}$-Uridine Incorporation

\begin{tabular}{lcc}
\hline & \multicolumn{2}{c}{$\%$ Increase over control } \\
\cline { 2 - 3 } \multicolumn{1}{c}{ Treatment } & $\begin{array}{c}\text { Untreated } \\
\text { cells }\end{array}$ & $\begin{array}{c}\text { PDBu-treated } \\
\text { cells }\end{array}$ \\
\hline PMA $10^{-8} \mathrm{M}$ & $+48.9 \pm 6.6^{*}$ & $-2.2 \pm 4.4$ \\
ANP $10^{-7} \mathrm{M}$ & $-58.0 \pm 1.7^{*}$ & $-39.5 \pm 3.0^{*}$ \\
PMA $10^{-8} \mathrm{M}+$ ANP $10^{-7} \mathrm{M}$ & $+23.4 \pm 2.3^{\ddagger}$ & $-56.0 \pm 2.7^{* \ddagger}$ \\
\hline
\end{tabular}

Values are means \pm SEM, $n=8$.

$* P<0.05$, significantly different from control.

${ }^{\ddagger} P<0.05$, significantly different from PMA alone. 
flow cytometric analyses confirming the results of Geisterfer et al. (16) showed that AII caused the increase of cell size up to $50 \%$ over untreated control cells, accompanied by the increase of cellular protein content, reflecting the concentration-dependent stimulation of ${ }^{3} \mathrm{H}$-uridine and leucine incorporations by AII $\left(\mathrm{ED}_{50}=10 \mathrm{nM}\right)$. Recently, we have demonstrated that AII induces early activation of protooncogenes, c- $f o s$ and c-myc $(18,29)$, and the later inductions of PDGF, a potent mitogen (18), and TGF- $\beta$ (Gibbons, G. H., et al., unpublished observation). The time course of the increases of RNA and protein syntheses observed in the present study (Fig. $1 A$ ) is compatible with the temporal profile of the induction of these two growth factors. This result suggests that these growth factors are the possible mediator of AII-induced hypertrophic action. In fact, we observed that the antisense oligonucleotides complementary to PDGF mRNA attenuates AII-induced hypertrophy in RASM cells (30). TGF- $\beta$ is reported to inhibit serum $(1-10 \%)$-stimulated proliferation of RASM cells $\left(\mathrm{ED}_{50}\right.$ $=2 \mathrm{pM})$ and concurrently induce cellular hypertrophy (22). This means that TGF- $\beta$ may selectively inhibit serum-stimulated increase in DNA replication, while having little or no inhibition on serum-induced increase of protein synthesis. It has been supposed that TGF- $\beta$ may be a mediator of smooth muscle cell growth in vivo during wound repair and atherogenesis (10). We observed in the present study the potent stimulatory effect of TGF- $\beta$ on RNA and protein syntheses in RASM cells (Fig. 4), supporting the idea that TGF- $\beta$ is a potent hypertrophic factor. In this setting, we examined the effect of ANP on RNA and protein syntheses, both in the basal state and in AII- and TGF- $\beta$-stimulated states.

The present study confirms the previous reports of an antiproliferative effect of ANP on serum and PDGF-induced mitogenesis (31-33). More importantly, it demonstrates clearly for the first time that ANP inhibits vascular hypertrophy in RASM cells in a concentration-dependent manner. The concentration of ANP employed in this study exceeds the circulating level of plasma ANP encountered in physiological or pathophysiological conditions (34-36). However, we have previously studied the degradation of ANP in proteinase inhibitor- and EDTA-free culture media and showed that $80-90 \%$ of ANP immunoreactivity was lost during the initial 24-h incubation at $37^{\circ} \mathrm{C}(37)$. Therefore, the actual effective antihypertrophic concentration of ANP may be much lower. Thus it seems plausible to speculate that the ANP levels in the circulation may influence hypertrophic change of vascular smooth muscle cells in vivo. Furthermore, the local concentration of ANP accumulated in the tissue (e.g., blood vessel) may be much higher than that in the plasma. Indeed, a prolonged infusion of ANP ( $20 \mu \mathrm{g} / \mathrm{kg}$ per hr) to rats induced atrophy of zona glomerulosa cells of rat adrenals and lowered the plasma concentration of aldosterone without provoking significant changes in plasma renin activity, indicating that ANP exerted inhibitory effects on growth of rat zona glomerulosa in vivo (38).

As for ${ }^{3} \mathrm{H}$-uridine incorporation, ANP showed more pronounced inhibitory effect in the basal state rather than AIIstimulated state (Fig. 2). This phenomenon is comparable to the observation that the degree of relaxation of norepinephrine-contracted aorta produced by nitroprusside or 8-bromo cGMP was dependent on the dose of norepinephrine (39). At higher concentrations of norepinephrine, less relaxation was seen for nitroprusside or 8-bromo cGMP than at lower con- centration of norepinephrine. This result suggests that ANP exerts its antihypertrophic effect via the intracellular signaling pathway independent of AII-specific activation pathway for hypertrophy. Indeed, ANP also showed the inhibitory effect on hypertrophy induced by TGF- $\beta$, a potent hypertrophic factor, as well as by AII. Therefore, these experiments indicate a more generalized inhibitory effect of ANP on the hypertrophy of vascular smooth muscle cells.

Recently, molecular cloning has defined three types of natriuretic peptide receptors: the ANP-C receptor of relative molecular mass $60-70 \mathrm{~K}$, which is not coupled to cGMP production and may function in the clearance of $\operatorname{ANP}(25,26)$, and the ANP-A and B receptors of 120-140 K, which are membrane forms of guanylate cyclase $(23,24)$. It is generally accepted that the guanylate cyclase-linked receptors mediate the cellular effects of ANP. However, recent evidence suggests that ANP may exert some biological activities through a nonguanylate cyclase-linked receptor system. For example, Ganguly et al. reported that ANP $\left(10^{-8} \mathrm{M}\right)$ inhibited aldosterone secretion in calf adrenal glomerulosa cells, while 8-bromo cGMP (2 $\mathrm{mM}$ ) did not (40). In the present paper, we studied the receptor subtype that mediates the growth inhibiting effect of ANP. Our data showed that C-ANP [4-23], which shows much higher affinity to the ANP-C receptor than the guanylate cyclasecoupled receptors $(26,27)$, exerted little effect on the hypertrophy of RASM cells compared to ANP [1-28] (Fig. 5). This result suggests that the antihypertrophic effect of ANP is mediated by a guanylate cyclase-coupled receptor(s) (the ANP-A or $B$ receptor). Because the exogenous administration of a cGMP analogue, 8-bromo cGMP, mimicked the ANP effect (Fig. 6), the intracellular second messenger responsible for the antihypertrophic action of ANP seems to be cGMP. Indeed, recent data demonstrated that nitric oxide-generating vasodilators and 8-bromo cGMP can inhibit the proliferation of RASM cells (41).

Involvement of protein kinase $\mathrm{C}$ pathway in cell growth has been postulated (28). Indeed, our data show that PMA increased the rate of RNA synthesis (Table II). In the present study, ANP inhibited both basal and PMA-stimulated RNA synthesis. Furthermore, in protein kinase C-depleted cells,

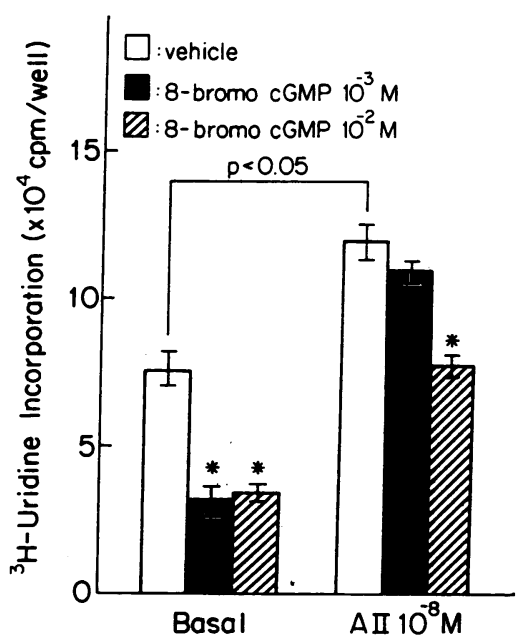

Figure 6. Effect of 8bromo cGMP on the basal and AII-stimulated RNA synthesis in RASM cells. 8-Bromo CGMP ( 1 or $10 \mathrm{mM}$ ) was added to the media of quiescent or AIIstimulated $\left(10^{-8} \mathrm{M}\right)$ RASM cells. 8-Bromo cGMP and AII were administered simultaneously and the cells were incubated for $16 \mathrm{~h}$ and pulsed with ${ }^{3} \mathrm{H}$-uridine $(2 \mu \mathrm{Ci} / \mathrm{ml})$ for the following $4 \mathrm{~h}$. TCA-Precipitable material was determined as described

above. Values are mean $\pm \operatorname{SEM}(n=6) .{ }^{*} P<0.05$ is significantly different from respective control groups without the treatment of 8 bromo cGMP. 
ANP still exerted its inhibitory effect on RNA synthesis. Thus, the antihypertrophic action of ANP appeared not to be dependent on protein kinase $\mathrm{C}$ activity. However, because it is also known that there is a protein kinase $\mathrm{C}$ isoform that is resistant to down-regulation in the rabbit aortic smooth muscle cells (42), the involvement of protein kinase $C$ activity in the antihypertrophic action of ANP cannot be completely ruled out. The elucidation of cellular mechanisms by which ANP inhibits hypertrophy of vascular smooth muscle cells awaits further investigation.

The present study demonstrates that ANP acts both as an antiproliferative as well as an antihypertrophic factor. These properties differ from those of TGF- $\beta$ which inhibits serum stimulated cell proliferation by prolonging cell-cycling time or inducing $G_{2}$ arrest, thereby increasing cell mass without division (22). In contrast, ANP exerts inhibitory effects, not only on DNA replication and cell division, but also on RNA and protein syntheses that mediate the increase in cell mass.

Vascular hypertrophy in hypertension is usually an adaptive process in response to increased arterial wall stress. However, the resultant increase in the wall-to-lumen ratio can lead to an amplified vasoconstrictive response to contractile agonists and may perpetuate hypertension. In hypertension, augmented secretion of ANP, which is not only a vasorelaxant but also an antihypertrophic peptide, may prevent the progression of hypertension by inhibiting the vascular hypertrophy, as well as reducing the vascular tone (9). The angiotensin converting enzyme inhibitor, captopril, not only reduced aortic smooth muscle cell contents in SHR (19) and two-kidney, one-clip hypertensive rats (43), but also decreased cross-sectional wall area of arterioles in one-kidney, one-clip hypertensive rats (44). These data indicate the crucial role of circulating and/or local renin angiotensin system(s) in the vascular growth of conduit and resistant vessels. The inhibition of AII-induced hypertrophy by ANP in the present study further suggests the compensatory role of ANP in hypertensive vascular change and also suggests a novel functional antagonistic relationship between ANP and renin angiotensin systems on cell growth. In addition, the general antimitogenic and antihypertrophic actions of ANP demonstrated in the present study suggest further the potential value of this peptide in the therapeutic application for hypertension.

\section{Acknowledgments}

This work is supported by National Institutes of Health (NIH) grants HL35610, HL35792, HL19259, HL35252, HL40210, HL42663, and NIH Specialized Center of Research in Hypertension HL36568.

\section{References}

1. De Bold, A. J., H. B. Borenstein, A. T. Veress, and H. Sonnenberg. 1981. A rapid and potent natriuretic response to intravenous injection of atrial myocardial extract in rats. Life Sci. 28:89-94.

2. Kangawa, K., and H. Matsuo. 1984. Purification and complete amino acid sequence of alpha-human atrial natriuretic polypeptide. Biochem. Biophys. Res. Commun. 118:131-139.

3. Needleman, P., S. P. Adams, B. R. Cole, M. G. Currie, D. M. Geller, M. L. Michener, C. B. Saper, D. Schwartz, and D. G. Standaert. 1985. Atriopeptins as cardiac hormones. Hypertension (Dallas). 7:469-498.

4. Cantin, M., and J. Genest. 1985. The heart and the atrial natriuretic factor. Endocr. Rev. 6:107-127.
5. Sugawara, A., K. Nakao, M. Sakamoto, N. Morii, T. Yamada, H. Itoh, S. Shiono, and H. Imura. 1985. Plasma concentration of atrial natriuretic polypeptide in essential hypertension. Lancet. ii:14261427.

6. Morii, N., K. Nakao, M. Kihara, A. Sugawara, M. Sakamoto, Y. Yamori, and H. Imura. 1986. Decreased content in left atrium and increased plasma concentration of atrial natriuretic polypeptide in spontaneously hypertensive rats (SHR) and SHR stroke-prone. Biochem. Biophys. Res. Commun. 135:74-81.

7. Imada, T., R. Takayanagi, and T. Inagami. 1985. Changes in the content of atrial natriuretic factor with the progression of hypertension in spontaneously hypertensive rats. Biochem. Biophys. Res. Commun. 133:759-765.

8. Sugimoto, T., M. Ishii, Y. Hirata, H. Matsuoka, T. Sugimoto, A. Miyata, T. Toshimori, H. Masuda, K. Kangawa, and H. Matsuo. 1986. Increased release of atrial natriuretic polypeptides in rats with DOCAsalt hypertension. Life Sci. 38:1351-1358.

9. Itoh, H., K. Nakao, M. Mukoyama, T. Yamada, K. Hosoda, G. Shirakami, N. Morii, A. Sugawara, Y. Saito, S. Shiono, H. Arai, I. Yoshida, and H. Imura. 1989. Chronic blockade of endogenous natriuretic polypeptide (ANP) by monoclonal antibody against ANP accelerates the development of hypertension in spontaneously hypertensive and deoxycorticosterone acetate-salt hypertensive rats. J. Clin. Invest. 84:145-154.

10. Dzau, V. J., and G. H. Gibbons. 1988. Cell biology of vascular hypertrophy in systemic hypertension. Am. J. Cardiol. 62:30G-35G.

11. Owens, G. K., and M. Reidy. 1985. Hyperplastic growth response of vascular smooth muscle cells following induction of acute hypertension in rats by aortic coarctation. Circ. Res. 57:695-705.

12. Bevan, R. D. 1976. An autoradiographic and pathologic study of cellular proliferation in rabbit arteries correlated with an increase in arterial pressure. Blood Vessels. 13:100-128.

13. Owens, G. K., and S. M. Schwartz. 1982. Alterations in vascular smooth muscle mass in the spontaneously hypertensive rat. Circ. Res. 51:280-289.

14. Owens, G. K., and S. M. Schwartz. 1983. Vascular smooth muscle cell hypertrophy and hyperploidy in the Goldblatt hypertensive rat. Circ. Res. 53:491-501.

15. Campbell-Boswell, M., and L. A. Robertson, Jr. 1981. Effects of angiotensin II and vasopressin on human smooth muscle cells in vitro. Exp. Mol. Pathol. 35:265-276.

16. Geisterfer, A. A. T., M. J. Peach, and G. K. Owens. 1988. Angiotensin II induces hypertrophy, not hyperplasia of cultured rat aortic smooth muscle cells. Circ. Res. 62:749-756.

17. Taubman, M. B., B. C. Berk, S. Izumo, T. Tsuda, R. W. Alexander, and B. Nadal-Ginard. 1989. Angiotensin II induces c-fos mRNA in aortic smooth muscle role of $\mathrm{Ca}^{2+}$ mobilization and protein kinase C activation. J. Biol. Chem. 264:526-530.

18. Naftilan, A. J., R. E. Pratt, and V. J. Dzau. 1989. Induction of platelet-derived growth factor A-chain and c-myc gene expressions by angiotensin II in cultured rat vascular smooth muscle cells. J. Clin. Invest. 83:1419-1424.

19. Owens, G. K. 1985. Differential effects of antihypertensive therapy on vascular smooth cell hypertrophy, hyperploidy, and hyperplasia in the spontaneously hypertensive rat. Circ. Res. 56:525-536.

20. Itoh, H., K. Nakao, G. Katsuura, N. Morii, S. Shiono, M. Sakamoto, A. Sugawara, T. Yamada, Y. Saito, A. Matsushita, and H. Imura. 1986. Centrally infused atrial natriuretic polypeptide attenuates exaggerated salt appetite in spontaneously hypertensive rats. Circ. Res. 59:342-347.

21. Owens, G. K., and L. G. Thompson. 1986. Expression of smooth muscle specific isoactin in cultured vascular smooth muscle cells: relationship between growth and cytodifferentiation. J. Cell Biol. 102:343-352.

22. Owens, G. K., A. A. T. Geisterfer, Y. W.-H. Yang, and A. Komoriya. 1988. Transforming growth factor- $\beta$-induced growth inhibition and cellular hypertrophy in cultured vascular smooth muscle cells. J. Cell Biol. 107:771-780. 
23. Chinkers, M., D. L. Garbers, M.-S. Chang, D. G. Lowe, H. Chin, D. V. Goeddel, and S. Schulz. 1989. Molecular cloning of a new type of cell surface receptor: a membrane form of guanylate cyclase is an atrial natriuretic peptide receptor. Nature (Lond.). 338:78-83.

24. Lowe, D. G., M.-S. Chang, R. Hellmiss, S. Singh, E. Chen, D. L. Garbers, and D. V. Goeddel. 1989. Human atrial natriuretic peptide receptor defines a new paradigm for second messenger signal transduction. EMBO (Eur. Mol. Biol. Organ.) J. 8:1377-1384.

25. Fuller, F., J. G. Porter, A. E. Arfsten, J. Miller, J. W. Schilling, R. M. Scarborough, J. A. Lewicki, and D. B. Schenk. 1988. Atrial natriuretic peptide clearance receptor. J. Biol. Chem. 263:9395-9401.

26. Maack, T., M. Suzuki, F. A. Almeida, D. Nossenzweig, M. Scarborough, G. A. McEnroe, and J. A. Lewicki. 1987. Physiological role of silent receptors of atrial natriuretic factor. Science (Wash. DC). 238:675-678.

27. Suga, S., K. Nakao, M. Mukoyama, Y. Kambayashi, Y. Saito, H. Arai, K. Hosoda, G. Shirakami, M. Jougasaki, Y. Ogawa, T. Yamada, K. Inoue, and H. Imura. 1990. Characterization of receptors for natriuretic peptides, ANP-BNP. In 13th Scientific Meeting of the International Society of Hypertension. IIH.13. (Abstr.)

28. Berk, B. C., V. Vekshtein, H. M. Gordon, and T. Tsuda. 1989. Angiotensin II-stimulated protein synthesis in cultured vascular smooth muscle cells. Hypertension (Dallas). 13:305-314.

29. Naftilan, A. J., R. E. Pratt, C. S. Eldridge, H. L. Lin, and V. J. Dzau. 1989. Angiotensin II induces c-fos expression in smooth muscle cell via transcriptional control. Hypertension (Dallas). 13:706-711.

30. Itoh, H., R. E. Pratt, and V. J. Dzau. 1990. Antisense oligonucleotides complementary to PDGF mRNA attenuate angiotensin IIinduced vascular hypertrophy. In 44th Annual Fall Conference and Scientific Sessions for Council for High Blood Pressure Research of the American Heart Association. No. 46. (Abstr.)

31. Johnson, A., F. Lermioglu, U. C. Garg, R. Morgan-Boyd, and A. Hassid. 1988. A novel biological effect of atrial natriuretic hormone: inhibition of mesangial cell mitogenesis. Biochem. Biophys. Res. Commun. 152:893-897.

32. Appel, R. G. 1988. Growth inhibitory activity of atrial natriuretic factor in rat glomerular mesangial cells. FEBS (Fed. Eur. Biochem. Soc.) Lett. 238:135-138.

33. Abell, T. J., A. M. Richards, H. Ikram, E. A. Espiner, and T. Yandle. 1989. Atrial natriuretic factor inhibits proliferation of vascular smooth muscle cells stimulated by platelet-derived growth factor. Biochem. Biophys. Res. Commun. 160:1392-1396.

34. Sugawara, A., K. Nakao, N. Morii, M. Sakamoto, M. Suda, M. Shimokura, Y. Kiso, M. Kihara, Y. Yamori, K. Nishimura, J. Soneda,
T. Ban, and H. Imura. 1985. Alpha-human atrial natriuretic polypeptide is released from the heart and circulates in the body. Biochem. Biophys. Res. Commun. 129:439-446.

35. Itoh, H., K. Nakao, T. Yamada, N. Morii, A. Sugawara, S. Shiono, Y. Saito, M. Mukoyama, H. Arai, G. Katsuura, M. Eigyo, A. Matshushita, and H. Imura. 1987. Modulatory role of vasopressin in secretion of atrial natriuretic polypeptide in conscious rats. Endocrinology. 120:2186-2188.

36. Itoh, H., K. Nakao, A. Sugawara, Y. Saito, M. Mukoyama, N. Morii, T. Yamada, S. Shiono, H. Arai, K. Hosoda, and H. Imura. 1988. Gamma-atrial natriuretic polypeptide (gamma-ANP)-derived peptides in human plasma: co-secretion of $\mathrm{N}$-terminal gamma-ANP fragment and alpha-ANP. J. Clin. Endocrinol. \& Metab. 67:429-437.

37. Itoh, H., K. Nakao, S. Shiono, M. Mukoyama, N. Morii, A. Sugawara, T. Yamada, Y. Saito, H. Arai, Y. Kambayashi, K. Inoue, and $H$. Imura. 1987. Conversion of $\beta$-human atrial natriuretic polypeptide into alpha-human atrial natriuretic polypeptide in human plasma in vitro. Biochem. Biophys. Res. Commun. 143:560-569.

38. Mazzocchi, G., P. Rebuffat, and G. G. Nussdorfer. 1987. Atrial natriuretic factor (ANF) inhibits the growth and the secretory activity of rat adrenal zona glomerulosa in vivo. J. Steroid Biochem. 28:643646.

39. Lincoln, T. M. 1982. Effects of nitroprusside and 8-bromo-cyclic GMP on the contractile activity of the rat aorta. J. Pharmacol. Exp. Ther. 224:100-107.

40. Ganguly, A., S. Chiou, L. A. West, and J. S. Davis. 1989. Atrial natriuretic factor inhibits angiotensin-induced aldosterone secretion: not through cGMP or interference with phospholipase C. Biochem. Biophys. Res. Commun. 159:148-154.

41. Garg, V. C., and A. Hassid. 1989. Nitric oxide-generating vasodilators and 8-bromo-cyclic guanosine monophosphate inhibit mitogenesis and proliforation of cultured rat vascular smooth muscle cells. J. Clin. Invest. 83:1774-1777.

42. Kariya, K., and Y. Takai. 1987. Distinct functions of down-regulation-sensitive and -resistant types of protein kinase $C$ in rabbit aortic smooth muscle cells. FEBS (Fed. Eur. Biochem. Soc.) Lett. 219:119-124.

43. Levy, B. I., J. B. Michel, J. L. Salzmann, M. Azizi, P. Poitevin, M. Safor, and J. P. Camilleri. 1988. Effects of chronic inhibition of converting enzyme on mechanical and structural properties of arteries in rat renovascular hypertension. Circ. Res. 63:227-239.

44. Wang, D.-H., and R. L. Prewitt. 1990. Captopril reduces aortic and microvascular growth in hypertensive and normotensive rats. $\mathrm{Hy}$ pertension (Dallas). 15:68-77. 